\title{
Opinions of Art Teachers on the Standards of the International Society for Technology in Education: The Case of Western Mediterranean Region, Turkey
}

\author{
Armağan Konak \\ Correspondence: Armağan Konak, Faculty of Education, Mehmet Akif Ersoy University, Turkey. \\ Received: December 12, 2017 \\ Accepted: February 4, $2018 \quad$ Online Published: February 15, 2018 \\ doi:10.11114/jets.v6i3.2858 \\ URL: https://doi.org/10.11114/jets.v6i3.2858
}

\begin{abstract}
The purpose of this study, which is based on qualitative data, is to reveal the opinions of art teachers on the teacher standards set by the International Society for Technology in Education.

It has been observed that the majority of participants of a study group are not aware of these standards, use social networks but do not use mobile applications, use the Internet for information-research purposes, and follow a news from the Internet. The participants think that students should be directed to conscious Internet use and must be educated accordingly.

The study group is of the opinion that technology and the teachers' field knowledge should be included in education training to facilitate the learning of students and to stimulate their creativity. Group members also believe that classical education and original activity design should be utilized in the design and development of learning experiences and evaluation activities, and the use of technology and applications that focus on students in order to be an example on studying and learning in this information age is needed. According to the participants, art teachers should inform students about conscious use of the Internet, and teach them to integrate life-long learning with real-life situations by participating in professional development-leadership activities. One of the participants thinks that excessive use of technology during classes will make students become used to excessive comfort. Another participant is of the opinion that the use of technology in the learning environment will not be useful.
\end{abstract}

As a result of the study, the following suggestions are offered.

- Art teachers can be informed about teacher standards.

- Art teachers can be given training about involving technology in teaching-learning processes, about learning experiences and the design of the evaluation activities, and life-long learning and professional development.

- Studies that emphasize the importance of the use of technological resources in education can be conducted.

- Art teachers can be informed about conscious Internet use.

Keywords: visual arts teacher, teacher standards, technology in education

\section{Introduction}

In line with the requirements of the Information Age, it is aimed for students, who are trapped between the trio of pencil, notebook and blackboard, to use the highest level available of technological resources to access information. In creating an Information Society, the rapid transformation of the age and the process of globalization cause changes in education and learning needs of individuals at all levels (Gürbüz, 2006: 373-375). For this reason, every new technological resource should be used in a functional manner in the educational environment. The amount of student knowledge can be increased in a multifaceted manner. Many studies have shown that the educational use of technology has an important role in the development of the student's analysis and implementation (Le Conseil Ontarien des Directeurs de L'Education (CODE), 2011:Avis No:3). From this point of view, there is a need for teachers to encourage students in the teaching environment, design and develop learning experiences and evaluation activities, become a model to students, and actively participate in their own professional development and leadership activities. Therefore, it is important for teachers to know and apply the standards of the International Society for Technology in Education (ISTE).

A road map for transforming education, the ISTE standards help innovative educators to re-engineer and reimagine their 
classrooms and schools for digital-age learning. They are a guide for amplifying and empowering learning, no matter where you are on the journey to the effective and meaningful integration of ed tech (Free ISTE Standards for Educators Resource).

The degree to which art teachers consider themselves adequate within the framework of the Standards of the ISTE constitutes the problem case of this study.

The aim of the study set out in the framework of the problem case is to determine opinions of a study group of art teachers on the teacher standards regarding the education technologies determined by the ISTE. In the study, a semi-structured interview method was applied.

\section{Method}

\subsection{Research Model}

This is a case study based on qualitative data and in this study a semi-structured interview technique was used. In this study, the opinions of art teachers about the teacher standards set by the ISTE were used. For this purpose, a semi-structured interview method was applied. Semi-structured interviews have been based because of their certain level of standard and flexibility, which are based on writing and completing tests and helping to remove limitations in the questionnaires and obtain in-depth information on a specific topic (Yıldırım ve Şimşek, 2008). The interview form was developed by the researcher. The data were collected from a total of 15 art teachers.

\subsection{Study Group}

The study group for this research consists of a total of 15 art teachers who graduated from the Department of Art Teaching of a university located in the Western Mediterranean region of Turkey.

The demographic characteristics of the study group are given in Figures 1, 2, 3, 4 below.

The gender characteristics of the study group are given in Table 1 below.

Table 1. The Gender Features of the study group

\begin{tabular}{ll}
\hline Gender & Quantity \\
\hline Male & 9 \\
Femal & 6 \\
\hline
\end{tabular}

The study group consisted of six female and nine male participants.

The information on the grade-point average of the study group is given in Table 2 below.

Table 2. Grade Average of the study group

\begin{tabular}{ll}
\hline Quantity & Grade Average \\
\hline 7 & $3.01-3.50$ \\
6 & $2.51-3.00$ \\
2 & $2.00-2.50$ \\
\hline
\end{tabular}

Two of the participants in the study group have a grade average of 2.00-2.50; 6, 2.51-3.00; and 7, 3.01-3.50.

Information on the social networking sites used by the study group is shown in Table 3 below.

Table 3. The study group's Use of Social Networking Sites

\begin{tabular}{ll}
\hline Social Networking Site & Quantity \\
\hline Facebook & 6 \\
Twiter & 4 \\
Isuu.com & 1 \\
Sinefesto & 1 \\
Onedio.com & 1 \\
Not Using & 2 \\
\hline
\end{tabular}

Thirteen of the participants in the study group use social networking sites, while two of them do not use any of them. When we look at the distribution of social networking site users, it is seen that six of the participants use Facebook; four of them use Twitter; one of them uses issuu.com; one of them uses Sinefesto; and one of them uses onedio.com.

The information on mobile applications that the study group uses is shown in Table 4 below.

Table 4. The study group's Mobile Application Use

\begin{tabular}{ll}
\hline Mobil Application & Quantity \\
\hline Whatsapp & 3 \\
Not Using & 12 \\
\hline
\end{tabular}


Three of the participants in the study group use mobile applications and 12 do not.

The information on the purpose of the Internet use by the study group is given in Table 5 below.

Table 5. The study group's Purpose of Internet Use

\begin{tabular}{ll}
\hline Internet & Quantity \\
\hline Research Information & 9 \\
Communacation-Sharing & 5 \\
Folloving the Agenda & 5 \\
Entertaintment & 4 \\
\hline
\end{tabular}

When we look at the group members' purpose of Internet use, we see that nine of them use it for research-information purposes; five for communication-sharing; five for receiving news; and four for entertainment purposes. Group members' use internet for multiple purposes.

Information about the study group's following the agenda on the Internet is given in Table 6 below.

Table 6. The study group's Use of the Internet for Following the Agenda

\begin{tabular}{ll}
\hline Following the Agenda & Quantity \\
\hline Yes & 12 \\
No & 3 \\
\hline
\end{tabular}

When the study group is considered in terms of using the Internet for following the agenda, it is seen that 12 of the participants follow the agenda on the Internet, and that three of them do not use the Internet for this purpose.

\subsection{Data Collection Tools}

In this study, an interview form developed by the researcher was used as the data collection tool. The interview form is composed of 10 questions to reveal the opinions of the art teachers regarding the teacher standards set by the ISTE. The questions were formed considering the following points of the art teachers;

1. Demographic characteristics (gender, grade average, use of social networking sites, use of mobile applications, purpose of Internet use, following the agenda on the Internet);

2. Facilitating students' learning and encouraging their creativity;

3. Designing and developing learning experiences and evaluation activities in line with the requirements of the Digital Age;

4. Being a model for studying and learning in the Information Age;

5. Encouraging individuals and setting an example for them regarding the responsibilities that they should have in the Information Society;

6. Participating in professional development and leadership activities.

\subsection{Data Analysis}

In this respect, the interview form and the analysis of the obtained data were presented to an expert reviewer, and the feedback used to reassess and revise the form with the purpose of providing content validity (Yıldırım, Şimşek, 2008).

The interview form created by the researcher in order to collect the data was applied to 15 art each art teacher were recorded with the help of a voice recorder, after obtaining their permission. Each interview lasted approximately 20 minutes. The data obtained from the research were separated into themes and interpreted in the context of Descriptive Analysis, which is a Qualitative Analysis Method. Some art teachers' opinions are collected under several themes or more than one.

\section{Findings}

A total of eight themes were identified under five headings as a result of the analysis. The titles obtained in the analysis of the collected data in the interview with the art teacher are listed below.

1. Learning and encouragement of creativity.

2. Activity design and development.

3. Model for students.

4. Responsibility awareness.

5. Professional development.

The titles and themes emerging from the analysis of the data obtained from this study are presented in tabular form and the frequency analysis results for these themes are briefly summarized in the tables below.

Frequency distributions of the study group members' opinions on encouraging learning and creativity are presented in 
Table 7 below.

Table 7. Frequency Distributions of Opinions on Encouraging Learning And Creativity

\begin{tabular}{lc}
\hline Theme & $\boldsymbol{f}$ \\
\hline 1. Field knowledge & \\
Self-assessment & 1 \\
Technological & 1 \\
comfort & \\
2. Education & \\
$\begin{array}{l}\text { Supplementary } \\
\text { resources }\end{array}$ & 11 \\
Assignments & 1 \\
Sharing & 1 \\
PC games & 1 \\
\hline
\end{tabular}

The opinions of the study group members' on facilitating students learning and encouraging their creativity seem to accumulate under the themes of field knowledge and education.

Under the theme of field knowledge, one participant thinks that self-evaluation of the art teacher is important for encouraging students' learning and creativity, and one thinks that overuse of technological resources will create an addiction of comfort for the student instead of motivating him/her.

Under the theme of education, 11 participants think that the means of technology should be seen as a supplementary resource during the lesson, one participant thinks that technology should be used when giving student assignments, one thinks that technology should be used in sharing things regarding lessons, and one thinks that computer games should be used as lesson materials.

Frequency distributions of study group members' opinions for designing and developing activities are presented in Table 8 below.

Table 8. Frequency Distributions of Opinions for Designing and Developing Activities

\begin{tabular}{lc}
\hline Theme & $f$ \\
\hline 1. Classical Education & 1 \\
Student feedback & 2 \\
Activities linked to the plans & 1 \\
Surveys & 1 \\
Technology is useless & \\
2. Unique Activity Design & 2 \\
Applications centered on digital technology & 1 \\
Conscious use of the Internet & 4 \\
Course-related web page design & 1 \\
No idea &
\end{tabular}

The opinions of the study group members on designing and developing learning experiences and evaluation activities seem to concentrate under the themes of classical education and unique activity design.

Under the theme of classical education, one participant thinks that student feedback is important, two think that activities linked to the plans are important, and one thinks that survey studies are important in designing and developing learning experiences and evaluation activities. One participant thinks that the use of technology in the learning environment is not beneficial.

Under the theme of unique activity design, one participant thinks that the applications centered on digital technology will be beneficial, two think that teaching students how to use the Internet consciously will be beneficial, and four think that designing and using web sites intended for the course will be beneficial. One participant does not have an opinion on designing and developing learning experiences and assessment activities.

Frequency distributions of study group members' opinions on being a model are presented in Table 9 below.

Table 9. Frequency Distributions of Opinions on Being a Model

\begin{tabular}{ll}
\hline Theme & $f$ \\
\hline 1. The Use of Technology & \\
Technology-based activities & 5 \\
Internet-based activities & 3 \\
Use of Social Networking Sites & 1 \\
Personal web page & 1 \\
Information On Internet use & 1 \\
2. Student-Centered & \\
Presentation preparation & 3 \\
\hline
\end{tabular}


The opinions of the study group members' on being a model in studying and learning seem to accumulate under the theme of student-centered applications.

Under the theme of technology use, five participants think that the art teacher's planning of tech-based activities is important, three think that adoption of Internet-based education by the art teacher is important, one thinks that using social networks is important, and one thinks that art teachers giving information on how to use the Internet is important in being a model for the student in terms of studying and learning.

Under the theme of the student-centered applications, three participants think that having students prepare presentations is important in becoming a model for the student in studying and learning terms.

Frequency distributions of study group members' opinions on responsibility awareness are presented in Table 10 below.

Table 10. Frequency Distributions of Opinions on Responsibility Awareness

\begin{tabular}{lr}
\hline Theme & $f$ \\
\hline Encouraging consciousness & \\
Conscious use of the Internet & 10 \\
Informing parents & 1 \\
Informing about research & 1 \\
No idea & 4 \\
\hline
\end{tabular}

The opinions of the study group members' on promoting responsibility and being a model seem to concentrate under the theme of encouraging consciousness.

Under the theme of encouraging consciousness; 10 participants think that guiding students to using the Internet consciously and educating them on this issue is important, one thinks that it is important to inform parents about using the Internet consciously, one thinks that educating students on how to conduct research on the Internet is important in terms of encouraging individuals about the responsibilities that an individual who is a member of the Information Society needs to have and being a model. Four participants have no opinion on this issue.

Frequency distributions of opinions toward professional development are presented in Table 11 below.

Table 11. Frequency Distributions of Opinions Toward Professional Development

\begin{tabular}{ll}
\hline Theme & $\boldsymbol{f}$ \\
\hline Life-long learning & \\
Symposium & 3 \\
In-service education & 1 \\
Conferences & 2 \\
Online courses & 1 \\
Seminars & 2 \\
Self-organizing & 1 \\
Biennials & 4 \\
Exhibitions & 1 \\
No idea & 6 \\
\hline
\end{tabular}

We see that the opinions of the study groups on participating in professional development and leadership activities concentrate under the theme of life-long learning.

Under the theme of life-long learning, three participants support in symposiums, one supports participation in in-service training, two support participation in conferences, one supports participation in online courses, one supports seminars, one supports participation in biennials, one supports exhibitions, and one supports participation in organizing his own professional development and leadership activities . Six participants have no idea about this issue.

\section{Results}

In the study, the following results have been obtained.

- The majority of the study group are not aware of the art teacher standards set by the ISTE.

- The majority of the study group use a social networking site but do not use a mobile application.

- The majority of the study group use the Internet for information-research purposes.

- The majority of the study group follows the agenda on the Internet.

- The study group thinks that the art teacher's field knowledge and the inclusion of technology in teaching-learning activities play an important role in facilitating learning and encouraging creativity.

- The study group is of the opinion that classical education and unique activity design can be uses in the design and development of learning experiences and evaluation activities. 
- In the study group, one person thinks that the overuse of technological resources during a lesson will create an addiction of comfort for the students instead of motivating them. Likewise, one person believes that the use of technology in the learning environment will not be useful.

- The majority of the study group argues that it is important that students be guided toward conscious use of Internet and educated on this issue.

- The study group considers technology use and student-centered applications important in becoming a role model for studying and learning in the Information Age.

- The study group has the opinion that art teachers should inform their students about using the Internet consciously in order to promote a feeling of responsibility in them for using technology and to be a role model for them.

- The study group thinks that art teachers' involvement in professional development and leadership activities depends on their integration to the concept of life-long learning.

In this research, the results obtained are mostly gathered on learning-teaching staffs and learning resources. Şimşek also conducted similar research in 2005. The research was carried out by Şimşek (2005) and revealed differences in views of education technology as a discipline and the practices of education technologies in various countries. A total of 71 experts from 12 universities in six countries participated in this earlier survey by the survey method. The results support the idea that the functions of educational technology in various fields are mostly related to learning-teaching processes and learning resources. Professional views about the current state of discipline have shown that there is no significant difference in the problems encountered in different countries.

\section{Suggestions}

The following suggestions can be made within the framework of the above results obtained in the research.

- Art teachers can be informed about the teacher standards set by the International Society of Educational Technologies and the results can be observed.

- Research on methods of designing and developing activities for teachers through technology can be conducted.

- Teachers can be given seminars on how to teach conscious Internet use to their students.

- Guidance can be given to teachers to provide professional development and the results can be evaluated.

\section{References}

Glesne, C. (2012). Introduction to Qualitative Research. Ankara. Anı Yayıncılık.

Gürbüz, T. (2006). E-Learning in Globalization Process. XV. National Congress of Educational Sciences. September 13-15. Muğla University. Muğla. Turkey.

Gökçe, O. (2006). Content Analysis Theoretical and Practical Information. Ankara. Siyasal Kitabevi.

Utilisation Efficace De La Technologie. Council of Directors of Education (CODE). 30 Juin 2011:Avis No:3 Web: http://www.ontariodirectors.ca/CODE_Advisories/Downloads/Avis_3.pdf date of access: 05.04.2017.

Yıldırım, A., \& Şimşek, H. (2008). Qualitative research methods in the social sciences.Ankara. Seçkin Yayıncılık.

\section{Copyrights}

Copyright for this article is retained by the author(s), with first publication rights granted to the journal.

This is an open-access article distributed under the terms and conditions of the Creative Commons Attribution license which permits unrestricted use, distribution, and reproduction in any medium, provided the original work is properly cited. 